\title{
PERLINDUNGAN KARYA SENI FOTOGRAFI BERDASARKAN \\ UNDANG- UNDANG NOMOR 19 TAHUN 2002 \\ TENTANG HAK CIPTA
}

\author{
Nurul Liza Anjani, ${ }^{1}$ Etty Susilowati ${ }^{2}$
}

\begin{abstract}
ABSTRAK
Penelitian ini bertujuan untuk mengetahui syarat suatu karya cipta fotografi agar memperoleh perlindungan Hak Cipta dan bagaimana bentuk perlindungannya. Tujuan lainnya adalah menguraikan dampak perlindungan Hak Cipta terhadap hak- hak seorang Pencipta (dalam hal ini fotografer) dan bagi pihak yang melanggar ketentuan Hak Cipta atas karya seni fotografi. Metode penelitian yang digunakan adalah penelitian hukum normatif. Keseluruhan data dianalis menggunakan analisis kualiutiatif. Hasil penelitian ditemukan bahwa Untuk memperoleh perlindungan Hak Cipta, suatu karya seni fotografi tidak perlu melewati tahap pendaftaran terlebih dahulu, karena secara otomatis setelah karya tersebut diwujudkan dalam bentuk nyata dan dipamerkan ke khalayak umum maka karya tersebut telah memperoleh pengakuan Hak Cipta dan dilindungi Hak Cipta. Hasil lainnya adalah Perlindungan Hak Cipta atas karya seni fotografi diberikan untuk melindungi hak- hak seorang Pencipta yakni Hak Ekonomi dan Hak Moral.
\end{abstract}

Kata Kunci: Fotografi, Karya Seni Fotografi, Hak Kekayaan Intelektual

1 Mahasiswa Program Studi Magister IImu Hukum UNDIP.

${ }^{2}$ Dosen Program Studi Magister Ilmu Hukum UNDIP 


\section{A. Latar Belakang}

Pelanggaran terhadap

karya cipta, dalam hal ini pada karya seni fotografi, sering terjadi terutama yang berkaitan dengan status kepemilikan haknya. Sebenarnya, status kepemilikan atas suatu foto sudah jelas ketentuannya yakni dimiliki oleh orang yang pertama kali menciptakan serta mempublikasikannya ciptaannya, dalam hal ini fotografer. Hal ini sesuai dengan prinsip First to Invent dalam Hak Cipta. Salah satu masalah yang seringkali dihadapi oleh seorang fotografer adalah ketika ia bekerja sebagai karyawan dan berada dibawah suatu perjanjian kuasa, terlebih lagi ketika salah satu pihaknya tidak paham betul mengenai apa yang telah diperjanjiakan sebelumnya berkaitan dengan hak kepemilikan atas foto- foto yang telah tercipta.

\section{Berdasarkan}

uraian tersebut maka dapat dirumuskan beberapa permasalahan yaitu apakah syarat suatu karya cipta fotografi agar memperoleh perlindungan Hak Cipta dan bagaimana bentuk perlindungannya. Apakah dampak perlindungan Hak Cipta terhadap hak- hak seorang Pencipta (dalam hal ini fotografer) dan bagi pihak yang melanggar ketentuan Hak Cipta atas karya seni fotografi.

\section{Metode Penelitian}

Metode penelitian yang dipergunakan dalam penulisan tesis ini adalah metode penelitian yuridis normatif. Pendekatan yuridis normatif ini dilakukan dengan mengambil bahan- bahan pustaka yang lazimnya dikatakan sebagai data sekunder.

\section{Kerangka Teori}

Hak Cipta atau Copyright menurut Pasal 1 ayat (1) Undang- Undang Nomor 19 Tahun 2002 tentang Hak Cipta merupakan hak eksklusif bagi Pencipta atau Penerima Hak untuk mengumumkan atau memperbanyak Ciptaannya atau memberikan izin untuk itu dengan tidak mengurangi pembatasan- pembatasan menurut peraturan perundangundangan yang berlaku.

\begin{tabular}{lrr}
\multicolumn{4}{c}{ Seorang } & Pencipta & belum \\
tentu bertindak & sebagai \\
Pemegang & Hak & Cipta. \\
Pemegang & Hak & Cipta
\end{tabular}
berdasarkan Pasal 1 ayat (4) adalah Pencipta sebagai Pemilik Hak Cipta, atau pihak yang menerima hak tersebut dari Pencipta, atau pihak lain yang menerima lebih lanjut hak dari pihak yang menerima hak tersebut.

Berdasarkan pengertian tersebut maka dapat diketahui bahwa Pemegang Hak Cipta bisa saja orang lain yang memperoleh pengalihan Hak Cipta melalui pewarisan, hibah, wasiat, perjanjian tertulis, atau sebab- sebab lain yang dibenarkan oleh peraturan perundang- undangan. Hal ini sesuai dengan ketentuan Pasal 3 ayat (1 dan 2) UndangUndang Nomor 19 Tahun 2002 tentang Hak Cipta.

Pada dasarnya dalam Hak Cipta tidak diperlukan adanya suatu sistem pendaftaran Hak Cipta, akan tetapi pendaftaran ini pada akhirnya akan 
diperlukan ketika seorang Pemilik suatu karya cipta mendapati adanya pelanggaran Hak Cipta atas karya- karyanya dan harus membawa permasalahan ini ke pengadilan. Hakim hanya dapat menentukan siapa Pencipta yang sebenarnya apabila pihakpihak yang berkepentingan dapat membuktikan kebenaran akan karya- karyanya tersebut. Hak Cipta mengenal 2 (dua) Hak Eksklusif yang dimiliki oleh seorang pencipta, yakni Hak Ekonomi dan Hak Moral. Hak Ekonomi atau Economic Rights pada dasarnya adalah hak yang dimiliki oleh seorang Pencipta untuk memperbanyak (reproduction right), mengumumkan (distribution right) dan mengadaptasi (adaptation right) ciptaannya. ${ }^{3}$ Hak ekonomi ini diberikan sebagai bentuk balas jasa kepada Pencipta atas hasil karyanya yang dapat berupa penghargaan atau royalti.

Hak Moral (Moral Right) dalam Hak Cipta adalah suatu hak yang melekat pada diri si Pencipta dan tidak dapat dialihkan, atau dengan kata lain hak moral adalah hak yang melekat dan melindungi kepentingan pribadi si Pemegang Hak Cipta. Pada umumnya, hak moral ini merupakan hak seseorang untuk diakui sebagai Pencipta atas suatu Ciptaan dan mencakup hak agar ciptaannya

3 M. Djumhana, R. Djubaedillah, op. cit., 51. tidak diubah atau dirusak tanpa persetujuan dari si Pencipta.

Pelaksanaan hak moral dapat kita lihat dalam pencantuman nama Pencipta pada ciptaannya, walaupun Hak Cipta atas ciptaannya tersebut telah dijual untuk dimanfaatkan oleh pihak lain. Hal ini diatur lebih lanjut dalam Pasal 24-26 Undang- Undang Nomor 19 Tahun 2002 tentang Hak Cipta. Hak Cipta Hak Cipta memiliki batasan waktu dalam hal kepemilikan Hak Ciptanya. Adapun batasan waktu kepemilikan Hak Cipta tersebut diberikan dalam jangka waktu selama hidup Pencipta dan terus berlangsung hingga 50 (lima puluh) tahun setelah Pencipta meninggal dunia. Hal ini sebagaimana tercantum dalam ketentuan Pasal 29 ayat (1j) Undang- Undang Nomor 19 Tahun 2002 tentang Hak Cipta.

Pembatasan waktu kepemilikan Hak Cipta sebagaimana dijelaskan di atas bertujuan agar Hak Cipta tidak tertahan lama pada tangan seorang Pencipta sebagai pemiliknya sehingga setelah si Pencipta meninggal dunia ditambah 50 (lima puluh) tahun setelahnya, hak tersebut dapat dinikmati oleh masyarakat luas secara umum sebagai milik umum (public domain), artinya bahwa masyarakat boleh mengumumkan atau memperbanyak ciptaan tersebut tanpa harus meminta izin terlebih dahulu kepada Pencipta atau Pemegang Hak Cipta dan tindakan tersebut 
tidak dianggap sebagai pelanggaran Hak Cipta.

Fotografi itu sendiri pada dasarnya berasal dari bahasa Yunani yaitu "photos" yang artinya cahaya dan "grafo" yang berarti melukis/ menulis, jadi fotografi adalah proses melukis/ menulis dengan media cahaya, atau dengan kata lain proses atau metode untuk menghasilkan gambar dari suatu objek dengan merekam pantulan cahaya yang mengenai objek tersebut pada media yang peka cahaya. ${ }^{4}$

Perkembangan teknologi dan informasi yang terjadi sekarang ini membawa pengaruh yang cukup besar pada dunia fotografi, dimulai dari perkembangan kamera yang semakin canggih hingga media publikasi yang semakin beragam dan mudah. Cara publikasi foto melalui media internet memang tergolong cepat, mudah, dan murah namun bukannya tanpa masalah. Internet sebagai sarana mempublikasi suatu karya terkadang tidak dilengkapi dengan aturan pengamanan yang cukup untuk melindungi karya seni yang diunggah kedalamnya.

Setiap orang bebas diseluruh dunia dapat mengakses hasil karya seni fotografi seorang fotografer apabila ia telah mengetahui alamat website yang digunakan sebagai media publikasi bahkan bebas untuk mengunduh hasil karya tersebut untuk dijadikan

$4 \quad$ http://id.m.wikipedia.org/wiki/Fotografi, diakses pada tanggal 1 Desember 2012, pada pukul 09.00 WIB. koleksi pribadi. Semua kemudahan tersebut pada akhirnya membuka peluang besar bagi pihak- pihak yang tidak bertanggung jawab untuk memanfaatkannya demi keuntungan komersiil.

Kasus pencurian Hak Cipta atas karya seni fotografi melalui media internet kerap kali terjadi, tidak hanya terjadi pada fotografer- fotografer yang tunduk pada peraturan hukum yang sama akan tetapi juga terjadi pada fotograferfotografer yang tunduk pada peraturan hukum yang berbeda atau lintas negara. Disinilah Undang- Undang Nomor 19 Tahun 2002 pada pasalpasalnya dituntut untuk dapat mengakomodasi kepentingan para Pemilik dan Pemegang Hak Cipta atas karya seni fotografi ketika terjadi pelanggaran terhadap karyakaryanya.

\section{B. Hasil Penelitian Dan} Pembahasan

\section{Syarat Memperoleh Perlindungan Hak Cipta dalam Kegiatan Karya Seni Fotografi dan Bentuk Perlindungannya}

Suatu karya pada dasarnya dapat dilindungi oleh Hak Cipta dengan catatan karya tersebut memiliki kriteria antara lain, bahwa karya tersebut merupakan karya orang itu sendiri (originality), dan karya tersebut bukan dalam bentuk ide karena karya yang masih berbentuk ide yang masih berada di alam pikiran si Pencipta tidak dilindungi oleh 
Hak Cipta. Ide tersebut harus sudah diwujudkan dalam bentuk yang nyata (fixation) serta karya tersebut merupakan ciri kreativitas Pencipta atau Pemegang Hak Cipta atau dengan kata lain memiliki kekhasan tertentu. ${ }^{5}$ Hasil karya seni fotografi dapat dianggap sebagai karya cipta yang dilindungi Hak Cipta apabila memenuhi unsur- unsur tersebut. Seorang fotografer yang hanya memiliki ide, kreatifitas dan orisinalitas, belum tentu akan mendapatkan cap sebagai Pencipta karya seni fotografi apabila ide- idenya, kreatifitasnya, serta keorisinalitasannya tersebut belum diwujudkan ke dalam suatu bentuk yang nyata, yakni foto.

Karya seni tersebut tidak perlu didaftarkan, dan pendaftaran yang dilakukan semata hanya untuk kepentingan pembuktian di muka Pengadilan ketika suatu saat timbul sengketa yang berkaitan dengan kepemilikan Hak Cipta atas karya- karya tersebut. Pembuktian sebagaimana telah dijelaskan sebelumnya ada dalam klaim yang diajukan oleh seorang Pencipta.Ada beberapa cara yang dapat dilakukan oleh seorang fotografer untuk melindungi hasil karya fotografinya selain berdasarkan pada ketentuan yang telah diatur dalam

http://www.trademarkindonesia.com/id/ hakcipta.html, diakses pada tanggal 22 Maret 2012, pada pukul 01.34 WIB.
Undang- Undang Nomor 19

Tahun 2002 tentang Hak

Cipta. Cara- cara tersebut antara lain dengan menggunakan teknik Digital Watermarking dan memperkecil resolusi suatu foto. Kedua teknik ini adalah cara yang paling umum digunakan oleh para Pencipta karya seni digital untuk melindungi hasil ciptaannya

2. Dampak Perlindungan Hak Cipta Terhadap Hak- Hak Pencipta (dalam hal ini fotografer) dan Bagi PihakPihak yang Melanggar Ketentuan Hak Cipta

Perlindungan Hak Cipta memiliki arti yang sangat penting bagi seorang Pencipta. Perlindungan Hak Cipta ini selain melindungi karyakarya seorang Pencipta dari tindakan plagiarisme, pencurian dan lain sebagainya, dan yang terpenting adalah melindungi hak- hak dari seorang Pencipta. Hak- hak ini sangat berpengaruh pada reputasinya sebagai Pencipta. Hal ini berkaitan dengan perlindungan Hak Ekonomi (hak untuk memperoleh keuntungan materiil dari sebuah karya ciptaannya) dan Hak Moral seorang Pencipta (biasanya lebih kepada pengakuan masyarakat atas eksistensi diri si Pencipta sebagai pemilik atas suatu karya).

Hal ini berbanding terbalik dengan kenyataan bahwa Perlindungan Hak Cipta ini memberikan banyak kerugian bagi para pihak yang 
telah melanggar ketentuan Hak Cipta ini. Tidak saja kerugian materiil yang dialami oleh para pelaku pelanggaran Hak Cipta ini, akan tetapi yang lebih buruk lagi menimbulkan kerugian imateriil baginya. Kerugian materiil bagi pihak- pihak yang melanggar ketentuan Hak Cipta dapat berupa dijatuhinya sanksi pidana, perdata, maupun administratif. Selain sanksi materiil yang dapat dijatuhkan pada para pihak yang melanggar ketentuan Hak Cipta, sanksi yang tidak dapat terlepas dari pihak- pihak yang melanggar Hak Cipta adalah sanksi immateriil yaitu beban moral yang terus ditanggung oleh pelanggar Hak Cipta. Pada kasus pelanggaran Hak Cipta atas suatu karya seni fotografi, apabila pihak yang melanggar tersebut adalah sama- sama berprofesi sebagai fotografer, maka sanksi moral yang akan terus melekat pada dirinya adalah dia tidak lagi dianggap sebagai fotografer yang memiliki ide- ide, kreatifitas, serta keorisinalitasan sendiri. Tindakan ini jelas akan menghambat kemajuan kariernya sebagai seorang fotografer dan menghambat kariernya sebagai fotografer di masa yang akan datang.

\section{Kesimpulan Dan Saran}

Berdasarkan uraian singkat di atas, makadapat ditarik kesimpulan sebagai berikut: Pertama, Untuk memperoleh perlindungan Hak Cipta, suatu karya seni fotografi tidak perlu melewati tahap pendaftaran terlebih dahulu, karena secara otomatis setelah karya tersebut diwujudkan dalam bentuk nyata dan dipamerkan ke khalayak umum maka karya tersebut telah memperoleh pengakuan Hak Cipta dan dilindungi Hak Cipta. Apabila dilakukan pendaftaran maka hal tersebut dilakukan sematamata untuk kepentingan pembuktian apabila kelak dikemudian hari timbul sengketa yang berkaitan dengan Hak Cipta atas fotofoto tersebut; Kedua, Perlindungan Hak Cipta atas karya seni fotografi diberikan untuk melindungi hak- hak seorang Pencipta yakni Hak Ekonomi dan Hak Moral.

\section{Saran}

Sehubungan dengan hasil- hasil penelitian yang dikemukakan penulis dalam penulisan ini, maka beberapa saran yang dapat dikemukakan adalah sebagai berikut:

a. Seorang fotografer sebenarnya tidak perlu melakukan pendaftaran terhadap ciptaanciptaannya sebab karya yang telah berbentuk foto tersebut secara otomatis akan menjadi miliknya dan memperoleh perlindungan Hak Cipta, akan tetapi seyogianya para fotografer melakukan pendaftaran di Dirjen HAKI untuk berjaga- jaga apabila dikemudian hari terjadi sengketa yang berkaitan 
dengan foto- fotonya terutama yang berkaitan dengan status kepemilikan fotofotonya.

b. Peraturan perundangan yang ada hendaknya dijadikan pegangan bagi para fotografer dalam menjalankan profesinya yang seringkali bersinggungan dengan tindakan pelanggaran Hak Cipta, sebab dalam karya- karyanya tersebut terdapat 2 hak penting Pencipta yang harus dijaga demi keberlangsungan profesinya sebagai fotografer. Peraturan ini juga diharapkan dapat menjadi ancaman dan peringatan bagi pihakpihak yang tidak bertanggungjawab yang hendak mengambil manfaat dari suatu karya seni fotografi untuk kepentingan pribadi.

\section{DAFTAR PUSTAKA}

Usman, Rachmadi, 2002, "Hukum Hak atas Kekayaan Intelektual: Perlindungan dan Dimensi Hukumnya di Indonesia”, PT. Alumni, Bandung.

Maulana, Insan Budi, dkk ( ed ), 2000, "Kapita Selekta Hak Kekayaan Intelektual", Pusat Studi Hukum UI, Yogyakarta.

Locke, "Two Treatises of Government", 1988, Edited and Introduced by Peter Laslett.

Saidin, 2004, "Aspek Hukum Hak Kekayaan Intelektual”, PT. RajaGrafindo Persada, Jakarta.

Gautama, Sudargo, "Segi- Segi Hukum Hak Milik Intelektual", Bandung: PT. Eresco, 1995.

Lindsey, Tim, "Hak Kekayaan Intelektual Suatu Pengantar", Bandung: Alumni, 2006.

Sembiring, Sentosa, "Hak Kekayaan Intelektual dalam Berbagai Peraturan PerundangUndangan", Bandung: Yrama Widya, 2006.

Sutendi, Adrian, "Hak Atas Kekayaan Intelektual", Jakarta: Sinar Grafika, 2009.

Soemitro, Hanintijo, Ronny, 1982, "Metodologi Penelitian Hukum”, Ghalia Indonesia, Jakarta.

Koentjaraningrat, 1991, "MetodeMetode Penelitian Masyarakat”, Gramedia, Jakarta.

Hozumi, Tamotzu "Asian Copyright Handbook”, 2006, Japan Copyright Office, Japan, hlm. 12.

Sandiasmo, "Majalah Foto Video", 2012, PT. Gramedia, Jakarta.

Fadli, Muhammad, 2011, "Workshop Pacu Jawi: Melesat di Dalam Lumpur", PT. Gramedia, Jakarta.

Djumhana, M., Djubaedillah, 1993, "Hak Kekayaan Intelektual: Sejarah, Teori dan Praktek di Indonesia", Citra Aditya Bakti, Bandung.

Soekanto, S, dan S. Mamudji, 2003, "Penelitian Hukum Normatif: 
Suatu Tinjauan Singkatan”,

PT. Raja Grafindo Persada:

Cetakan Ketujuh, Jakarta.

Marzuki, P.M., 2005, "Penelitian

Hukum”, Kencana Prenada

Media Group, Jakarta. 